Vol. 10(11) pp. 327-332, November 2016

DOI: $10.5897 / A J F S 2016.1472$

Article Number: F30F4C 160711

ISSN 1996-0794

Copyright (C) 2016

African Journal of Food Science

Author(s) retain the copyright of this article

http://www.academicjournals.org/AJFS

\title{
Volatile compound analysis of the leaves and seeds of Piper guineense using gas chromatography-mass spectrometry (GC-MS)
}

\author{
Ojinnaka, M. C. ${ }^{1 *}$, Ubbor, S. C. ${ }^{1}$, Okudu, H. . $^{2}$ and Uga, U. ${ }^{1}$ \\ ${ }^{1}$ Department of Food Science and Technology, Michael Okpara University of Agriculture, Umudike, Abia State, Nigeria. \\ ${ }^{2}$ Department of Nutrition and Dietetics, Michael Okpara University of Agriculture, Umudike Abia State, Nigeria.
}

Received 31 May, 2016; Accepted 5 August, 2016

\begin{abstract}
The volatile compounds in the leaves and seeds of Piper guineense plant from South East Nigeria, were investigated using gas chromatography-mass spectrometry (GC-MS). The analysis was carried out to identify the compounds responsible for the characteristic flavor of the flavouring spices. A total of thirty-three volatile constituents were identified in the leaves and seeds of Piper guineense using GCMS. The major compounds identified include acids, esters, alcohols, hydrocarbons and others. Acids were found to be the predominant constituent group followed by esters. The leaves and seeds of Piper guineense had acids in the values of 65.56 and $53.72 \%$, respectively. The esters were also found to be more in the leaves $(25.63 \%)$ than in the seeds $(5.22 \%)$ of $P$. guineense. The hydrocarbons identified appeared more in the seeds (11.47\%) of $P$. guineense. The monoterpene (beta-myrcene) and sesquiterpenes (aromadendrene, trans-alpha-bergamotene, copaene) hydrocarbons identified were also present in the seeds than in the leaves of the $P$. guineense. Gamma-elemene, a sesquiterpene were identified in both the leaves and seeds of $P$. guineense at the same retention time of $10.242 \mathrm{~min}$ but at different concentrations of 0.41 and $0.72 \%$, respectively.
\end{abstract}

Key words: Piper guineense, volatile compounds, leaves, seeds.

\section{INTRODUCTION}

$P$. guineense is a spice plant from the family, Piperaceae and from the genus piper. The genus Piper is made up of about 1050 species of tropical shrubs, lianas, and small trees, many of which are important as spices and flavoring agents and medicines (Owolabi et al., 2013; Mabberley, 2008). P. guineense is a climbing plant that can grow up to $20 \mathrm{~m}$ in length. The seeds are smooth and are prolate-elliptically shaped. The seeds of the plant are commonly known in English-speaking countries as "West African black pepper", "uziza" in Igbo "iyeree" in Yoruba and "poivrie" in French. West African black pepper (Piper guineense) is an important plant used in traditional medicine and as spice. The fruits (the part of the plant traditionally used) are rich in a wide range of

*Corresponding author. E-mail: mcojinnaka@yahoo.co.uk.

Author(s) agree that this article remains permanently open access under the terms of the Creative Commons Attribution License 4.0 International License 
natural products including volatiles oils, lignans, amides, alkaloids, flavonoids and polyphenols (Rodolfo et al., 2013). The leaves and seeds are usually sold in Nigerian markets as an edible medicinal plant or additive in foods to offer aroma and flavor.

The seeds, leaves and sometimes the stems are used in preparing soup. It imparts "heat" and a spicy pungent aroma to food. The medicinal properties of $P$. guineese exert bacteriostatic and bacteriocidal effects on some bacteria. The leaves are considered aperitive, carminative and eupeptic. They are also used for the treatment of cough, bronchitis, intestinal disease and rheumatism (Okoye and Ebeledike, 2013; Sumathykutty et al., 1999). The leaves are also used for female infertility while, the fruits are used as an aphrodisiac (Echo et al., 2012). $P$. guineense has culinary, medicinal, cosmetic and insecticidal uses (Nwinyi et al., 2013; Okwute, 1992). The powder obtained from the ground seeds is used for its stimulating properties (Tchoumbougnang et al., 2009; Sofowora, 1982). $P$. guineense is added to food meant for pregnant and nursing mothers as a medicinal spice and among the post partum women, it is claimed that it assists in the contraction of the uterus (Achinewhu et al., 1995). Okoye and Ebeledike (2013) reported that the leaf extracts of $P$. guineese have antimicrobial effect on some test organisms. The leaf extracts exhibited antimicrobial effect activity due to the presence of tannins, saponins, flavonoids and alkaloids (Rabe and Vonstanden, 1987). The essential oils of $P$. guineense from Cameroon (Tchoumgougnang et al., 2009) and from Nigeria (Oyedeji et al., 2005) have also been studied.

Monoterpenes,sesquiterpenes and benzenoids(e.g. dildillapiole and myristicin) have been identified as the main compounds in $P$. guineense. In addition to their importance as a spice and for the flavoring of food products, this Piper species is also used in traditional African medicine, because of its various pharmacological effects (e.g. antimicrobial, insecticidal, anticonvulsive, antihypertensive, sedative and tranquillizing activities (Jirovetz et al., 2002). An investigation of the volatile compounds that contribute to the flavor characteristics of $P$. guineense from South East Nigeria by means of GCMS has not been performed previously. Therefore, the objective of this study was to identify the entire volatile compounds of the leaves and seeds of $P$. guineense responsible for the characteristic aroma of these natural flavourings and spices and to compare the volatile constituents in the leaves and seeds of the $P$. guineense plant.

\section{MATERIALS AND METHODS}

The seeds and leaves of $P$. guineense were purchased from Umuahia modern market, Urbani lbeku Abia State, Nigeria. The leaves and seeds of $P$. guineense were separated from the stem, sorted to remove debris. The leaves and seeds were washed separately and oven dried at $65^{\circ} \mathrm{C}$ for $4 \mathrm{~h}$ and milled into powder before further analysis.
Table 1. Percent composition of the different volatile compounds identified in the leaves and seeds of Piper guineense (\%).

\begin{tabular}{clcc}
\hline \multirow{2}{*}{ S/N } & \multirow{2}{*}{ Compounds } & Samples & $(\%)$ \\
\cline { 3 - 4 } & & Uziza leaves & Uziza seeds \\
\hline 1 & Acids & 65.56 & 53.72 \\
2 & Esters & 25.63 & 5.22 \\
3 & Alcohol & - & 1.90 \\
4 & Hydrocarbons & 6.96 & 11.47 \\
5 & Others & 1.88 & 27.66 \\
\hline
\end{tabular}

Determination of volatile compounds using gas chromatographic-mass spectral analysis

GC-MS analysis was carried out on a GC Clarus 500 Perkin Elmer system comprising of a AOC-20i auto- sampler and gas chromatograph interfaced to a mass spectrometer (GC-MS) instrument employing the following conditions: column Elite-1 fused silica capillary column $(30 \times 0.25 \mathrm{~mm}$ ID $\times 1 \mu \mathrm{M} d f$, composed of $100 \%$ dimethylpoly diloxane), operating in electron impact mode at $70 \mathrm{eV}$; helium $(99.999 \%)$ was used as carrier gas at a constant flow of $1 \mathrm{~mL} / \mathrm{min}$ and an injection volume of $0.5 \mu \mathrm{L}$ was employed (split ratio of $10: 1$ ) injector temperature $250^{\circ} \mathrm{C}$; ion-source temperature of $280^{\circ} \mathrm{C}$. The oven temperature was programmed from $110^{\circ} \mathrm{C}$ (isothermal for $2 \mathrm{~min}$ ), with an increase of $10^{\circ} \mathrm{C} / \mathrm{min}$, to $200^{\circ} \mathrm{C}$, then $5 \mathrm{C} / \mathrm{min}$ to $280^{\circ} \mathrm{C}$, ending with a 9 min isothermal at $280^{\circ} \mathrm{C}$. Mass spectra were taken at $70 \mathrm{eV}$; a scan interval of $0.5 \mathrm{~s}$ and Fragments from 40 to $450 \mathrm{Da}$. Total GC running time was $36 \mathrm{~min}$. N/B: Before GC-MS analysis, the plant is subjected to cold extraction process using ethanol as the solvent.

\section{Identification of components}

Interpretation on mass spectrum GC-MS was conducted using the database of National Institute Standard and Technology (NIST) having more than 62,000 patterns. The spectrum of the unknown component was compared with the spectrum of the known components stored in the NIST library. The name, molecular weight and structure of the components of the test materials were ascertained.

\section{RESULTS AND DISCUSSION}

The volatile compounds of the leaves and seeds of $P$. guineense analyses using GC-MS are shown in Tables 1 and 2. The gas chromatogram showed the relative concentrations of various compounds getting eluted as a function of retention time (Figures 1 and 2). The heights of the peak indicate the relative concentrations of the compounds of the components present in the plant extract (Negbenebor et al., 1999). A total of thirty-three volatile constituents were identified in the leaves and seeds of $P$. guineense. The compounds which were identified by GC-MS analysis were twenty-two for the leaves and twenty-five for the seeds of $P$. guineense. 
Table 2. Concentrations of volatile compounds in the leaves and seeds of Piper guineense.

\begin{tabular}{|c|c|c|c|c|c|}
\hline \multirow[t]{2}{*}{$\mathbf{S} / \mathbf{N}$} & \multirow{2}{*}{$\begin{array}{l}\text { Retention time } \\
\text { (minute) }\end{array}$} & \multirow[t]{2}{*}{ Compounds } & \multicolumn{2}{|r|}{ Area } & \multirow{2}{*}{$\begin{array}{c}\text { Normalized } \\
(\%)\end{array}$} \\
\hline & & & Formula & Uziza leaves & \\
\hline & & Acids & & & \\
\hline 1. & 11.858 & Dodecanoic acid & $\mathrm{C}_{12} \mathrm{H}_{24} \mathrm{O}_{2}$ & - & 2.48 \\
\hline 2. & 11.875 & Dodecanoic acid & $\mathrm{C}_{12} \mathrm{H}_{24} \mathrm{O}_{2}$ & 1.47 & - \\
\hline 3. & 14.258 & Tetradecanoic acid & $\mathrm{C}_{14} \mathrm{H}_{28} \mathrm{O}_{2}$ & - & 3.26 \\
\hline 4. & 14.267 & Tetradecanoic acid & $\mathrm{C}_{14} \mathrm{H}_{28} \mathrm{O}_{2}$ & 4.03 & - \\
\hline 5. & 17.942 & n-Hexadecanoic acid & $\mathrm{C}_{16} \mathrm{H}_{32} \mathrm{O}_{2}$ & - & 16.28 \\
\hline 6. & 17.958 & n-Hexadecanoic acid & $\mathrm{C}_{16} \mathrm{H}_{32} \mathrm{O}_{2}$ & 15.14 & - \\
\hline 7. & 20.783 & Oleic Acid & $\mathrm{C}_{18} \mathrm{H}_{34} \mathrm{O}_{2}$ & 33.37 & - \\
\hline 8. & 20.800 & Oleic Acid & $\mathrm{C}_{18} \mathrm{H}_{34} \mathrm{O}_{2}$ & - & 26.09 \\
\hline 9. & 21.033 & Octadecanoic acid & $\mathrm{C}_{18} \mathrm{H}_{36} \mathrm{O}_{2}$ & 8.22 & - \\
\hline 10. & 21.042 & Octadecanoic acid & $\mathrm{C}_{18} \mathrm{H}_{36} \mathrm{O}_{2}$ & - & 5.61 \\
\hline \multirow[t]{2}{*}{11.} & 23.292 & Eicosanoic acid & $\mathrm{C}_{20} \mathrm{H}_{40} \mathrm{O}_{2}$ & 3.33 & - \\
\hline & & Esters & & & \\
\hline 12. & 13.592 & Methyl tetradecanoate & $\mathrm{C}_{15} \mathrm{H}_{30} \mathrm{O}_{2}$ & 1.19 & - \\
\hline 13. & 16.883 & Pentadecanoic acid,14-methyl-,methyl ester & $\mathrm{C}_{17} \mathrm{H}_{34} \mathrm{O}_{2}$ & - & 1.28 \\
\hline 14. & 16.892 & Hexadecanoic acid,methyl ester & $\mathrm{C}_{17} \mathrm{H}_{34} \mathrm{O}_{2}$ & 6.53 & - \\
\hline 15. & 19.900 & 9,12-Octadecadienoic acid, methyl ester (E,E) & $\mathrm{C}_{19} \mathrm{H}_{34} \mathrm{O}_{2}$ & - & 0.74 \\
\hline 16. & 19.908 & 9,12-Octadecadienoic acid,methyl ester (E,E)- & $\mathrm{C}_{19} \mathrm{H}_{34} \mathrm{O}_{2}$ & 3.42 & - \\
\hline 17. & 19.992 & 11-Octadecenoic acid, methyl ester & $\mathrm{C}_{19} \mathrm{H}_{36} \mathrm{O}_{2}$ & - & 2.26 \\
\hline 18. & 20.008 & 11-Octadecenoic acid, methyl ester & $\mathrm{C}_{19} \mathrm{H}_{36} \mathrm{O}_{2}$ & 9.64 & - \\
\hline 19. & 20.350 & Octadecanoic acid methyl ester & $\mathrm{C}_{19} \mathrm{H}_{38} \mathrm{O}_{2}$ & 3.49 & 0.94 \\
\hline \multirow[t]{2}{*}{20.} & 22.792 & Eicosanoic acid, methyl ester & $\mathrm{C}_{21} \mathrm{H}_{42} \mathrm{O}_{2}$ & 1.36 & - \\
\hline & & Alcohol & & & \\
\hline \multirow{2}{*}{$\begin{array}{l}21 . \\
22 .\end{array}$} & 11.617 & 3,5,7-Cycloheptatriene-1,3-dimethanol & $\mathrm{C}_{9} \mathrm{H}_{12} \mathrm{O}_{2}$ & - & 1.90 \\
\hline & & Hydrocarbons & & & \\
\hline 23. & 8.967 & 1, 3, 6-Heptatriene, 2, 5, 5-trimethyl & $\mathrm{C}_{10} \mathrm{H}_{16}$ & - & 0.17 \\
\hline 24. & 9.142 & Copaene & $\mathrm{C}_{15} \mathrm{H}_{24}$ & - & 0.14 \\
\hline 25. & 9.542 & Cedrene & $\mathrm{C}_{15} \mathrm{H}_{24}$ & 0.26 & - \\
\hline 26. & 9.542 & trans-alpha-Bergamotene & $\mathrm{C}_{15} \mathrm{H}_{24}$ & - & 0.22 \\
\hline 27. & 9.717 & Cyclohexane,1-ethenyl-1-methyl-2,4-bis(1-methylethenyl) & $\mathrm{C}_{15} \mathrm{H}_{34}$ & 0.60 & 1.00 \\
\hline 28. & 10.158 & 1, 3, 6, 10-Dodecatraene,3, 7, 11-trimethyl-,(Z,E) & $\mathrm{C}_{15} \mathrm{H}_{24}$ & 0.44 & 0.62 \\
\hline 29. & 10.242 & gamma-Elemene & $\mathrm{C}_{15} \mathrm{H}_{24}$ & 0.41 & 0.72 \\
\hline 30. & 10.783 & Aromadendrene & $\mathrm{C}_{15} \mathrm{H}_{24}$ & - & 0.66 \\
\hline 31. & 10.925 & Tridecane & $\mathrm{C}_{13} \mathrm{H}_{28}$ & 1.27 & - \\
\hline 32. & 10.933 & $\begin{array}{l}\text { Cyclopropane, 1-(2-methylene-3-butenyl)-1-(1- } \\
\text { methylenepropyl }\end{array}$ & $\mathrm{C}_{12} \mathrm{H}_{18}$ & - & 1.14 \\
\hline 33. & 11.150 & beta-Myrcene & $\mathrm{C}_{10} \mathrm{H}_{16}$ & - & 2.26 \\
\hline 34. & 11.150 & Cyclohexene,1-methyl-4-(5-methyl-1-methyl-4-hexenyl) & $\mathrm{C}_{15} \mathrm{H}_{24}$ & 1.49 & - \\
\hline 35. & 11.358 & $\begin{array}{l}\text { Cyclohexe,3-(1,5-dimethyl-4-hexenyl)-6-methylene,[S- } \\
\left.\left(\mathrm{R}^{\star}, \mathrm{S}^{*}\right)\right]-\end{array}$ & $\mathrm{C}_{15} \mathrm{H}_{24}$ & 1.43 & 2.95 \\
\hline 36. & 12.142 & Undecane & $\mathrm{C}_{11} \mathrm{H}_{24}$ & 0.56 & - \\
\hline 37. & 13.375 & Heptadecane,2, 6-dimethyl- & $\mathrm{C}_{19} \mathrm{H}_{40}$ & 0.50 & - \\
\hline \multirow[t]{2}{*}{38.} & 17.325 & Cyclohexene,1-nonyl- & $\mathrm{C}_{15} \mathrm{H}_{28}$ & - & 1.59 \\
\hline & & Others & & & \\
\hline 39. & 12.125 & 1-Hydroxyl-1, 7-dimethyl-4-isopropyl-2, 7-cyclodecadiene & $\mathrm{C}_{15} \mathrm{H}_{26} \mathrm{O}$ & - & 1.48 \\
\hline 40. & 12.550 & Pyridine,3-(5-phenyl-4H-1, 2, 4-triazol-3-yl & $\mathrm{C}_{13} \mathrm{H}_{10} \mathrm{~N}_{4}$ & 1.88 & 2.36 \\
\hline 41. & 25.917 & $\begin{array}{l}\text { 3-[(4-methoxyl-benzoyl)-hydrazono]-N-(1-phenyl-ethyl)- } \\
\text { butyramide }\end{array}$ & $\mathrm{C}_{20} \mathrm{H}_{23} \mathrm{~N}_{3} \mathrm{O}_{3}$ & - & 15.94 \\
\hline 42. & 27.508 & $\begin{array}{l}\text { 3-[2-(3, 4-Dimethoxy-phenyl)-2-oxo-ethyl-3H-[1, 3, 4] } \\
\text { oxadiazol-2-one }\end{array}$ & $\mathrm{C}_{18} \mathrm{H}_{16} \mathrm{~N}_{2} \mathrm{O}_{5}$ & - & 7.88 \\
\hline
\end{tabular}



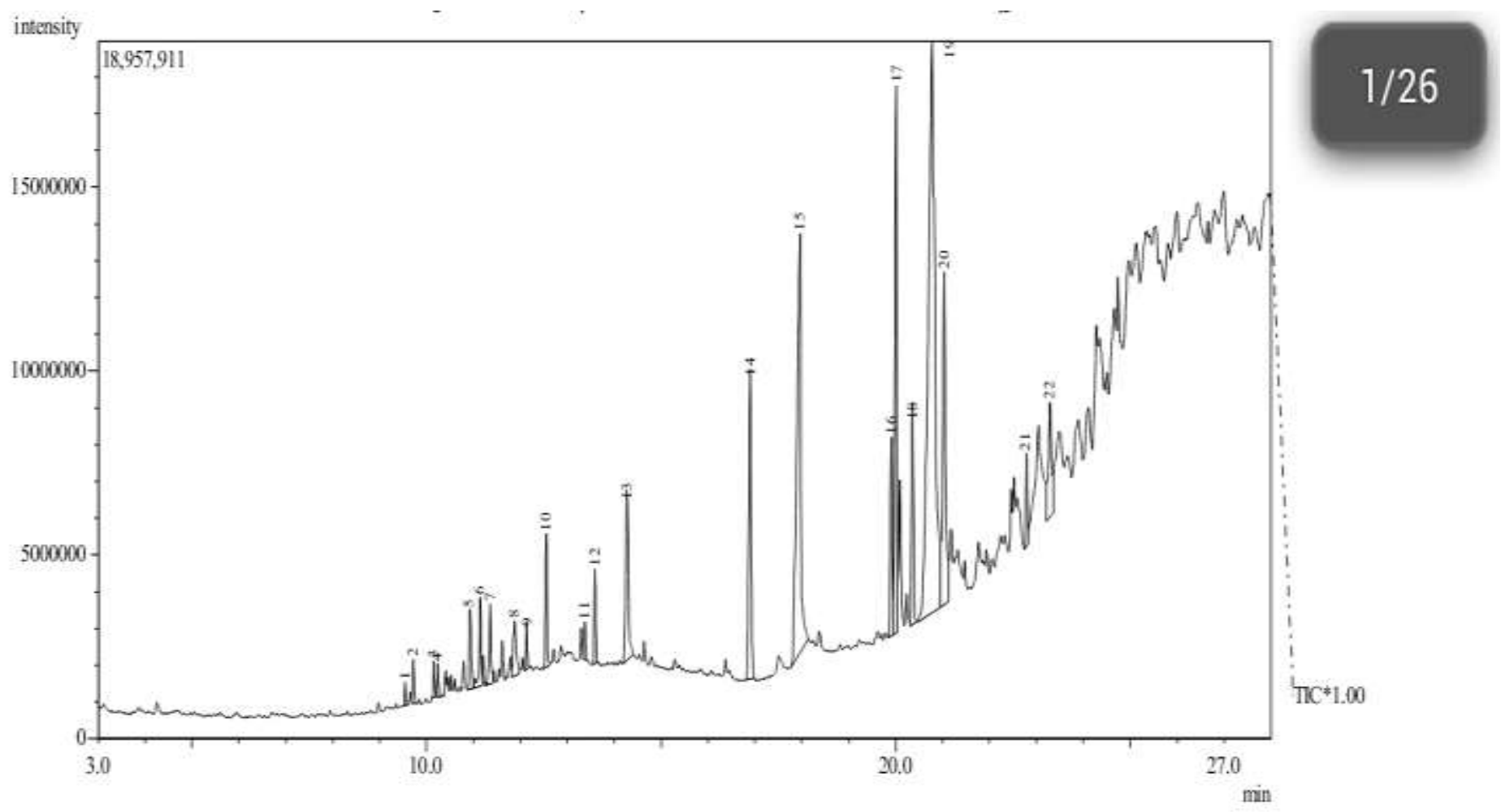

Method

Figure 1. Chromatograms of the volatile compounds in the leaves of Piper guineense.

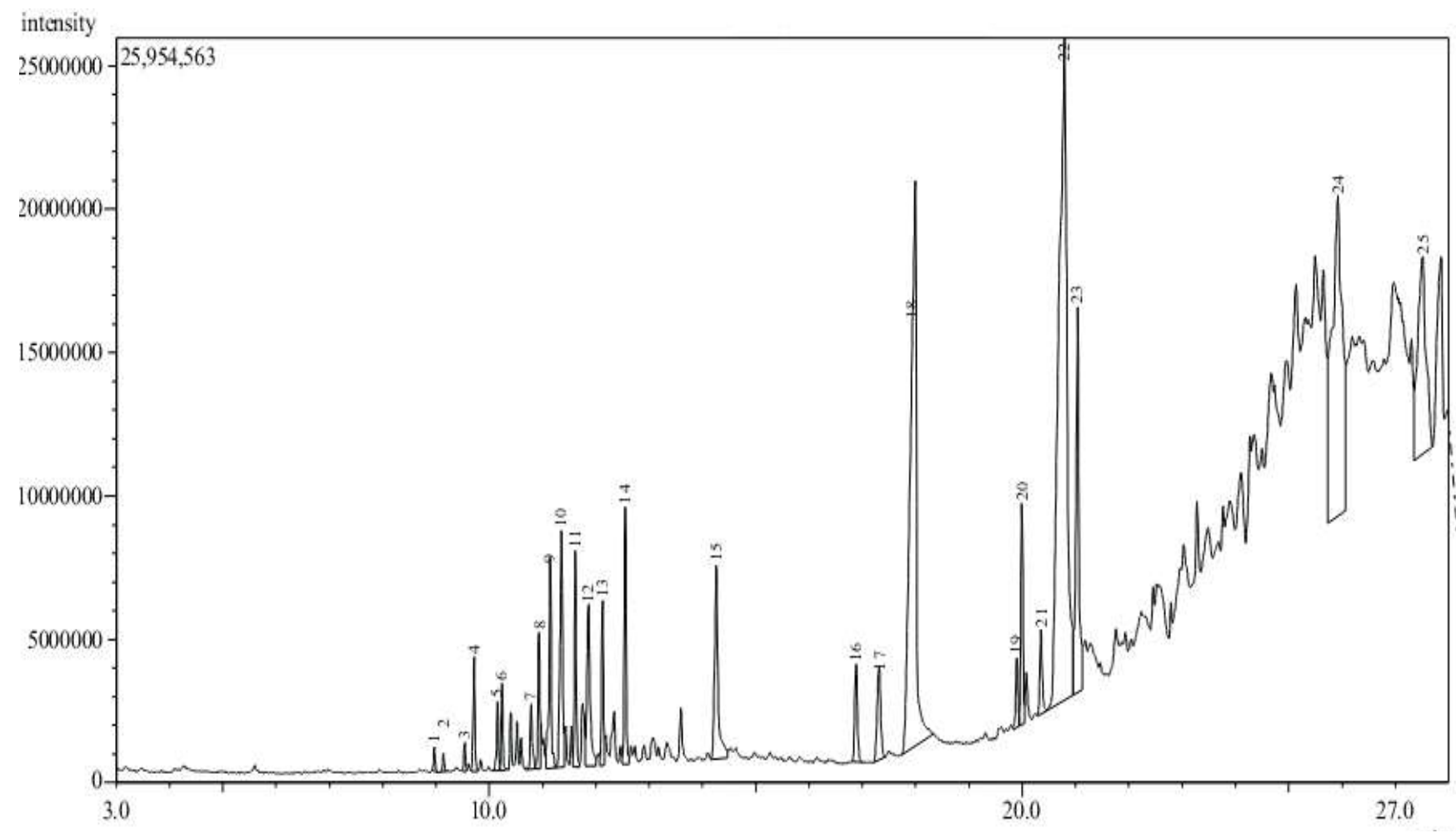

Figure 2. Chromatograms of the volatile compounds in the seeds of Piper guineense. 
The thirty-three volatiles are of various types; acids, esters, alcohol, hydrocarbons (mainly terpenes) and others (Table 1). Acids are the dominant constituent group from the result shown in Table 1 and constitute over $50 \%$ of total volatiles in the leaves and seeds of $P$. guineense. Ali and Ibiam (2014), also identified acids in their work on the phytochemical studies and GC-MS analysis of Gongronema latifolium and $P$. guineense. Acids identified in the leaves and seeds of $P$.guineense include dodecanoic acid, tetradecanoic acid, nhexadecanoic acid, oleic acid, octadecanoic acid and eicosanoic acid. They however occurred at different retention times. The highest concentration of the acids were found in oleic acids - $33.37 \%$ in $P$. guineense leaves and $26.09 \%$ in $P$. guineense seeds at retention time of 20.783 mins and 20.800 mins, respectively. However, oleic acid and hexadecanoic acid have been reported in the leaves of G. Iatifolium (Ali and Ibiam, 2014). Jirovetz et al. (2002) in their study of the aroma compounds in black Piper nigrum, white $P$. guineense and black $P$. guineense also identified some acids (acetic acid, propanoic acid, butanoic acid, nonanoic acid). Some of these acids are used in various industries as flavouring agents. Some organic acids have been determined as major aroma compounds in Korean soy sauces and barley bran sauces (Steinhaus and Schieberle, 2007).

Table 1 also shows that esters were also identified in the volatile compound analysis. The leaves of $P$. guineense had higher ester concentration than the seeds. Octadecanoic acid methyl ester occurred at the same retention time of $20.350 \mathrm{~min}$ in the leaves and seeds of $P$. guineense. But their concentrations were different; $P$. guineense leaves had a higher concentration of $3.49 \%$, while the $P$. guineense seeds had $0.94 \%$. Other ester compounds shown in Table 2 occurred at different time and with different constituents. Jirovetz et al. (2002) also identified esters (benzyl benzoate, phenylethyl benzoate) in $P$. nigrum and $P$. guineense. Esters, mainly formed by esterification of carboxylic acids and alcohols were reported to determine the characteristic pleasant aromatic notes (Klesk and Qian, 2003). The importance of ester contributions toward food aroma is undisputed with the fact that esters with low carbon atoms are highly volatile at ambient temperatures and the perception thresholds are ten times lower than their alcohol precursors (Nogueira et al., 2005). In addition to imparting a fruity floral character, esters can diminish or mask the sharpness of unpleasant FFA-derived notes. These esters are formed by esterification between the short-chain FFAs and the alcohols (Qin and Ding, 2007). 3,5,7-Cycloheptatriene-1,3-dimethanol was the only alcohol identified at $1.90 \%$ in the seeds of $P$. guineense at 11.617 min retention time. Alcohols are known to act as antifungal and prevent food spoilage (Onyenekwe et al., 2012).

Hydrocarbons (mainly terpenes) were also identified in the leaves and seeds of $P$. guineense plant. The seeds of $P$. guineense had higher concentration of the hydrocarbons which were mainly terpenes. Beta-myrcene (monoterpene) was identified only in the seeds of $P$. guineense at $2.26 \%$ concentration at a retention time of $11.150 \mathrm{~min}$. Gamma-elemene (sesquiterpenes) was identified in both the leaves and the seeds of $P$. guineense at the same retention time of $10.242 \mathrm{~min}$ at concentrations of 0.41 and $0.72 \%$, respectively. Other hydrocarbon sesquiterpenes identified only in the seeds of $P$. guineense include copaene, trans-alphabergamotene and aromadendrene. Owolabi et al. (2013) in their study of the aroma chemical composition of $P$. guineense from Lagos identified myrcene, alpha-copaene and beta-elemene in fruit (berries) of the plant. They also reported linalool as the major oil responsible for their characteristic flavor. Cedrene is a sesquiterpene that was identified only in the leaves of $P$. guineense at concentration of $0.26 \%$. Jirovetz et al. (2002) reported that monoterpenes, sesquiterpenes and benzenoids have been identified as the main compounds in $P$. guineense responsible for their characteristic flavor. They also identified similar aroma compounds in their analysis of the seeds of black $P$. nigrum, white $P$. guineense and black $P$. guineense. Some of the similar terpenes identified include myrcene, gamma-elemene, copaene and trans-alpha-mergamotene.

They reported that monoterpenes and sesquiterpenes particularly were found to be of essential importance for the fine and pleasant pepper aroma of the black pepper ( $P$. nigrum) and "Ashanti pepper" ( $P$. guineense). Sruthi et al. (2013) in their study on the correlation between chemical profiles of black pepper ( $P$. nigrum) collected from different locations in India reported the presence of monoterpenes like thujene, alpha-pinene, sabinene, limonene, alpha-phellandrene and linalool in samples collected at relatively higher altitudes as compared to plains. Other volatile compounds that were identified in the leaves and seeds of $P$. guineense were 1-hydroxyl-1, 7-dimethyl-4-isopropyl-2,7-cyclodecadiene, pyridine,3-(5phenyl-4H-1, 2, 4-triazol-3-yl, 3-[(4-methoxyl-benzoyl)hydrazono]-N-(1-phenyl-ethyl)-butyramide and 3-[2-(3, 4dimethoxy-phenyl)-2-oxo-ethyl-3H-[1, 3, 4] oxadiazol-2one. Pyridine,3-(5-phenyl-4H-1, 2, 4-triazol-3-yl) occurred in both the leaves and seeds of $P$. guineense at the same retention time of 12.550 min with concentrations 1.88 and $2.36 \%$, respectively.

\section{Conclusion}

A total of thirty-three volatile compounds were identified in the leaves and seeds of $P$. guineense comprising acids, esters, alcohols, hydrocarbons (mainly monoterpenes and sesquiterpenes) and others. The different volatile constituents isolated using the gas chromatography-mass spectrometry contributes to the 
aroma in the leaves and seeds of $P$. guineense and the final characteristic aroma of $P$. guineense leaves and seeds depend on the balance and interaction between the different components identified.

\section{Conflict of interests}

This research did not receive any specific grant from funding agencies in the public, commercial or not-forprofit sectors. The authors have not declared any conflict of interests.

\section{REFERENCES}

Achinewhu SC, Ogbonna CC, Hart AD (1995). Chemical composition of indigenous wild herbs, spices, fruits, nuts and leafy vegetables used as foods. Plant Foods Hum. Nutr. 48(4):341-348.

Ali FU, Ibiam UA (2014). Phytochemical Studies and GC-MS Analysis of Gongronema Latifolium and Piper Guineense, Int. J. Innov. Res. Dev. 3:108-115.

Echo IA, Osuagwu AN, Agbor RB, Okpako EC, Ekanem BE (2012). Phytochemical Composition of Aframomum melegueta and Piper guineense Seeds. World J. Appl. Environ. Chem. 2:17-21.

Jirovetz L, Buchbauer G, Ngassoum MB, Geissler M (2002). Aroma compound analysis of Piper nigrum and Piper guineense essential oils from Cameroon using solid-phase microextraction-gas chromatography, solid-phase microextraction-gas chromatographymass spectrometry and olfactometry. J. Chromatogr. A 976:265-275.

Klesk K, Qian M (2003). Preliminary aroma comparison of Marion (Rubus spp. Hyb) and Evergreen ( $R$. laciniatus L.) Blackberries by dynamic headspace/OSME Technique ( $\mathrm{RH}$ Marion and Evergreen Volatiles. J. Food Sci. 68:697-700.

Mabberley DJ (2008). Mabberley's Plant Book. $3^{\text {rd }}$ Ed. Cambrideg University Press, U.K.

Negbenebor CA, Godiya AA, Igene JO (1999). Evaluation of Clariasanguillains treated with spice (Piper guinnense) for washed mice and kama book type product. Food Compost. Anal. 2:12-315.

Nogueira MCL, Lubachevsky G, Rankin SA (2005). A study of the volatile composition of Minas cheese. LWT Food Sci. Technol. 38(5):555-563.

Nwinyi OC, Chinedu NS, Ajani, OO, Ikpo CO, Ogunniran KO (2009). Antibacterial effects of extracts of Ocimum gratissimum and piper guineense on Escherichia coli and Staphylococcus aureus. Afr. J. Food Sci. 3(1):22-25

Okoye El, Ebeledike AO (2013). Phytochemical constituents of Piper guineense (uziza) and their health implications on some microorganisms. Glob. Res. J. Sci. 2:42-46.
Okwute SK (1992). Plant derived pesticidal and antimicrobial agents for use in agriculture. A review of phytochemical and biological studies on some Nigerian plants. J. Agric. Sci. Technol. 2(1):62-70.

Onyenekwe PC, Odeh C, Nweze CC (2012). Volatile constituents of ogiri, soybean daddawa and locust bean daddawa, three fermented Nigerian food flavour enhancers. Electronic J. Environ. Agric. Food Chem. 11(1):15-22.

Owolabi MS, Lawal AO, Ogunwande IA, Hauser RM, Setzer WN (2013). Aroma chemical composition of Piper guineense Schumach. \& Thonn. From Lagos, Nigeria: a new chemotype. Am. J. Essent. Oils Nat. Prod. 1:37-40.

Oyedeji OA, Adeniyi BA, Ajayi O, König WA (2005). Essential oil composition of Piper guineense and its antimicrobial activity. Another chemotype from Nigeria. Phytother. Res. 19:362-364.

Qin L, Ding X (2007). Evolution of proteolytic tasty components during preparation of douchiba, a traditional Chinese soy-fermented Appetizer. Food Technol. Biotechnol. 45:85-90.

Rabe T, Vonstanden J (1987). Antimicrobial activity of someAfrican plants used for medicinal purposes. J. Ethnopharmacol. 56:81-87.

Rodolfo Juliani H, Koroch AR, Giordano L, Amekuse L, Koffa S, Asante-Dartey J, Simon JE (2013). Piper guineense (Piperaceae): Chemistry,Traditional Uses, and Functional Properties of West African Black Pepper. In. African Natural Plant Products Volume II: Discoveries and Challenges in Chemistry, Health, and Nutrition. Eds. Rodolfo Juliani H, James E. Simon \& Chi-Tang Ho. pp. 33-48.

Sofowora A (1982). Medicinal plants and traditional medicine in Africa. John Wiley. Chichester.

Sruthi S, Zachariah TJ, Leela NK, Jayarajan D (2013). Correlation between chemical profiles of black pepper (Piper nigrum L.) var. Panniyur-1 collected from different locations. J. Med. Plants Res. 7:2349-2357

Steinhaus $P$, Schieberle $P$ (2007). Characterization of the key aroma compounds in soy sauce using approaches of molecular sensory science. J. Agric. Food Chem. 55:6262-6269.

Sumathykutty MA, Rao JM, Padmakumari KP, Narayanan CS (1999). Essential oil constituents of some piper species. Flavors Fragr. J. 14:279-282.

Tchoumgougnang F, Jazet Dongmo PM, Sameza ML, Fombotioh N, Wouatsa Nangue AV, Amvam Zollo PH, Menut C (2009). Comparative essential oils composition and insecticidal effect of different tissues of Piper capense L., Piper guineense Schum. et Thonn., Piper nigrum L. and Piper umbellatum L. grown in Cameroon. Afr. J. Biotechnol. 8(3):424-431. 